\title{
Dynamic Relationship Between Voluntary Disclosure And Conservatism
}

\author{
Kyoungwon Mo, Korea Advanced Institute of Science and Technology (KAIST), South Korea
}

\begin{abstract}
Despite the several studies on the relationship between voluntary disclosure and conservatism, empirical findings are not conclusive. In this paper, I argue that the relation is not static but dynamic. I investigate the dynamic relation between voluntary disclosures and conservatism by examining their relation around debt financing. Debt financing can be a good natural experimental setting to examine the relation between voluntary disclosures and conservatism because both of them play an important role in reducing information asymmetry during debt financing. Particularly, I hypothesize that less conservative firms are more likely to increase voluntary disclosures around debt financing than at other times. Consistent with my hypothesis, empirical results show that less conservative firms are more likely to increase voluntary disclosures around debt financing than at other times. Overall, these results support the dynamic relationship between voluntary disclosures and conservatism.
\end{abstract}

Keywords: Conservatism; Voluntary Disclosure; Debt Financing

\section{INTRODUCTION}

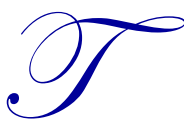

he voluntary disclosure of earnings forecasts gives the benefit of lowering the effective interest rate of debt by reducing information asymmetry between firms and creditors. Since creditors could be concerned that companies withhold information that could increase the default risk of the loan, or that the companies are not trustworthy in the disclosures that they made, creditors depend on public information to monitor a firm's default risk without biased information from borrowers (Mazumdat and Sengupta, 2005). Therefore, firms in anticipation of debt financing can have incentives to increase their disclosures to satisfy the creditors' needs. Sengupta (1998) suggests that firms with high disclosure quality can enjoy a lower effective interest cost of public debt. Similarly, Mazumdat and Sengupta (2005) argue that firms try to reduce information asymmetry by increasing their disclosures even before private debt financing.

Accounting conservatism is another method that firms have to reduce information asymmetry. Prior literature finds that conservatism substantial influences on a firm's cost of debt by reducing information asymmetry between firms and creditors. Positive Accounting theory explains that creditors need a mechanism for mitigating the downside risk to maximize the probability of steady repayment and accounting conservatism is eligible to serve as this 'mechanism' (Watts and Zimmerman, 1986) Empirical evidence generally supports the theoretical expectation. Watts and Zimmerman (1986) argue that conservatism improves the efficiency of debt contracting activities, and it gives a benefit of lowering the interest rate to the firms. Ahmed et al. (2002) argue that conservatism gives borrowers benefit of better debt ratings, which imply a lower interest rate. Moerman (2006) finds that more conservative firms enjoy a lower bid-ask spread in the secondary market. This lower bid-ask spread imply that conservatism offers more information to the lenders, so it gives discount on the corresponding portion of the cost of debt by relaxing the information asymmetry between the lenders and borrowers. Recently, Zhang (2008) suggests that conservatism benefits both lenders and borrowers: ex post benefits to lenders through timely signaling of default risk, and ex ante benefits to borrowers through lower initial interest rates.

Despite the common role in reducing information asymmetry, the relationship between conservatism and voluntary disclosure is still debatable. LaFond and Watts (2008) suggest that conservatism reduces the extent of information asymmetry by increasing the speed with which negative information is revealed in the earnings 
numbers, and thus conservatism can be a substitute for disclosures. Hui et al. (2009) provide empirical evidences on the substitution relationship between conservatism and management earnings forecast. On the other hand, Li and Zining (2008) argues that the impact of conservatism on voluntary disclosures is complementary since conservatism increases the probability that reported earnings will be unexpectedly low, analysts do not properly adjust for conservatism in their forecasts of future earnings and firms need to issue more forecasts to correct analysts' forecasts.

In this paper, I argue that the relation between voluntary disclosures and conservatism is not static but dynamic. To verify it, I investigate the dynamic relation between voluntary disclosures and accounting conservatism by examining their relation around debt financing. Particularly, I hypothesize that less conservative firms are more likely to increase voluntary disclosures around debt financing than at other times. In addition, I also examine the nature of the disclosures around debt financing. Since accounting conservatism is defined as a mechanism which forces a firm to recognize bad news quickly and good news slowly, a firm with high conservatism level would not need to release more bad news before debt financing to satisfy creditors' needs for it.

To test my hypotheses, I test all sample firms reporting at least one management earnings forecasts from 1996 to 2010. I identify a firm's level of conservatism with a firm-year conservatism measure of Khan and Watts (2009). Consistent with my hypothesis, the results show that less conservative firms are more likely to increase management earnings forecasts around debt financing than at other times. Second, more conservative firms are less likely to increase good news before debt financing than at other times. This result implies that the substitute relation between voluntary disclosures and conservatism is pronounced around debt offerings.

This study contributes to the literature in several ways. First, this paper adds empirical evidence on the strategic use of either voluntary disclosures or conservatism around debt financing. Second, more importantly, this paper finds that firms strategically change the level of their voluntary disclosures according to their conservatism lever before debt financing, which means dynamic substitute relation between voluntary disclosures and conservatism.

The reminder of this study is organized as follows. In sections 2, I review prior literature and develop my hypotheses. Section 3 describes sample and research methodology. Section 4 presents the empirical results and Section 5 summarizes and concludes this paper.

\section{LITERATURE REVIEW AND HYPOTHESES DEVELOPMENT}

\subsection{Voluntary Disclosures and Debt Financing}

Prior literature suggests that firms have incentives to increase voluntary disclosures before debt financing. Sengupta (1998) expects that since potential public debt holders do not have right to access borrowing firms' information, which is essential to evaluate the firm's default risk, firms with higher disclosure level would enjoy the lower cost of public debt. Consistent with her expectation, she finds that firms with high disclosure quality are more likely to have the lower yield-to-maturity and spread. Similarly, Mazumdat and Sengupta (2005) argue that firms financing through private debt can also enjoy the lower cost of the debt by increasing their disclosure level. They explain that although private lenders have direct access to inside information at their demand, private lenders are still attracted to voluntary disclosures because they help for private lenders to reduce information search cost. Moreover, in the case of asymmetric information, lenders would be concerned that companies withhold information that could increase the default risk of the loan or that the companies were not trustworthy in the disclosures that they made. Therefore, firms can use voluntary disclosures to alleviate these creditors' concerns over withholding information and in turn, to obtain lower cost of private debt. Their empirical results show that firms with high disclosure level are more likely to have lower cost of private debt.

The literature also shows that firms strategically increase their disclosures around debt offerings. Healy at al. (1999a) find that firms with increased analyst ratings of disclosures have an abnormally high frequency of subsequent public debt offers. Frankel et al. (2005) similarly find that firms are more likely to release disclosures before debt offerings. 


\subsection{Conservatism and Debt Financing}

Conservatism also has substantial influence on a firm's cost of debt financing. Conservatism improves the efficiency of debt contracting activities (Watts and Zimmerman, 1986) and gives borrowers the benefit of lowering the interest rate (Ahmed et al., 2002; Moerman, 2006; Zhang, 2008). In particular, Ahmed et al. (2002) provide empirical evidence that conservatism gives borrowers the benefit of better debt ratings, and in turn, firms with better debt ratings enjoy a lower interest rate. Moerman (2006) finds that more conservative firms enjoy a lower bid-ask spread in the secondary market. This lower bid-ask spread implies that conservatism offers more information to the lender, so it gives a discount on the corresponding portion of the cost of debt. Recently, Zhang (2008) suggests that conservatism benefits both lenders and borrowers: ex post benefits to lenders through timely signaling of default risk, and ex ante benefits to borrowers through lower initial interest rates. She argues that more conservative borrowers are more likely to violate debt covenants after experiencing a negative price shock.

Conservatism gives the benefit of lowering the interest rate for borrowers by reducing information asymmetry between firms and debt holders. According to positive accounting theory, lenders are widely known to bear only downside risk due to the deterministic structure of debt contracts (Fischer and Verrecchia, 1997; Plummer and Tse, 1999). Therefore, lenders need a means for mitigating the downside risk to maximize the probability of steady repayment. Watts and Zimmerman (1986) suggest that lenders would require a higher return or even refuse to lend without a proper mechanism to credibly mitigate their risk. Positive accounting also proposes that accounting conservatism is appropriate to serve as this 'mechanism' and allows borrowers to reduce the downside risk for lenders. Watts $(2003 \mathrm{a}, \mathrm{b})$ finds that they concentrate on the lower bounds of earnings and net asset distributions because of their concern with downside risk. Conservative accounting policies deliver more verifiable information on net assets and allow lenders to make better decisions on providing capital and to efficiently monitors the borrower's ability to pay. Consequently, accounting conservatism provides mitigation to the downside risks lenders are bearing.

\subsection{Voluntary Disclosures and Conservatism}

Although both voluntary disclosures and conservatism play a common role in reducing information asymmetry between firms and creditors, the relation between them is still controversy. Some scholars insist that the relation between conservatism and voluntary disclosures is a substitute. They argue that conservatism may affect management's forecasting strategy by altering the extent of information asymmetry between management and market participants. LaFond and Watts (2008) suggest that conservatism reduces the extent of information asymmetry by increasing the speed with which negative information is revealed in the earnings numbers. Since management has an incentive to overstate accounting earnings, firms reporting negative financial results are more reliable than those reporting positive financial results. In addition, they suggest that conservative financial statements are less likely to be manipulated to overstate earnings. Similarly, Li and Jing (2008) argues that conservatism increases the predictability of earnings by anticipating all losses, thereby reducing future uncertainty with regard to whether losses will be realized. Li and Jing (2008) further documents a negative relation between conservatism and absolute analyst forecast error, implying that conservatism increases analyst forecast accuracy. These findings together suggest that conservative accounting may substitute for management forecasts in reducing information asymmetry and the uncertainty of future earnings. A second link between conservatism and management's forecasting decisions relates to legal exposure, i.e., the need to preempt the disclosure of bad news (Skinner, 1994; Kasznik and Lev, 1995). By increasing the speed with which losses are recognized in earnings, conservatism could reduce the need to issue a preemptive forecast. This is consistent with Cahan and Zhang's (2006) finding that ex-Andersen clients adopt more conservative accounting in the post-Enron period. Hui et al. (2009) provide empirical evidences on the substitution relationship between conservatism and management earnings forecast. On the other hand, Li and Zining (2008) argues that the impact of conservatism on voluntary disclosures is complementary. She suggests that because conservatism increases the probability that reported earnings will be unexpectedly low, analysts do not properly adjust for conservatism in their forecasts of future earnings. She predicts that firms with conservative accounting will therefore need to issue more forecasts to correct analysts' forecasts. Louis et al. (2008) find consistent evidence by documenting a positive association between conservatism and negative forecast errors based on analysts' initial forecasts. As a result, conservatism is shown to increase the 
probability of a low earnings report, which would increase the need for a preemptive earnings forecast and lead to a positive relation between conservatism and management forecast frequency, specificity, and timeliness.

\subsection{Hypotheses Development}

To conclude the debate on the relation between voluntary disclosures and conservatism, I particularly consider debt financing. If the relation between voluntary disclosures and conservatism is not always substitute but it changes from time to time, debt financing can be a good experimental setting to figure the substitute relationships because both voluntary disclosures and conservatism are severely related to it. Therefore, if the relation between voluntary disclosures and conservatism is substitute around debt financing, less conservative firms are more likely to increase voluntary disclosures before debt financing as hypothesized below:

H1: A firm with a lower conservatism level is more likely to increase its management forecast before debt financing than at other times.

In addition, I examine the nature of the disclosures around debt financing. Firms tend to disclose more positive news (or less bad news) before debt financing because lenders examine the company's current and past voluntary disclosure to determine the extent of monitoring or agency costs, and a firm has incentives to show a better performance record to improve its credibility. However, the nature of conservatism forces a firm to recognize bad news quickly and good news slowly. Therefore, if the relation between conservatism on voluntary disclosures is substitute, more conservative firms are less likely to increase good news before debt financing as I hypothesize below:

H2: A firm with a higher conservatism level will be less likely to increase good news before debt financing than at other times.

\section{DATA AND METHODOLOGY}

\subsection{Conservatism}

Although conservatism is defined as 'a prudent reaction to uncertainty to try to ensure that uncertainty and risks inherent in business situations are adequately considered' in FASB No. 2, however, it is not identified by one generally accepted definition. Givoly and Hayn (2003) point out that the definition in FASB No.2 fails to either present the nature of 'prudent reaction' or explain how such a 'reaction' may ensure that risks are 'adequately considered'. In practice, accounting conservatism is widely referred to as allowing the recognition of losses quickly and gains slowly to ensure that all uncertainties are properly applied in the financial reports, and stating gains at the least optimistic estimate amount.

Particularly, I use the firm-year measure of Khan and Watts (2009). They suggest that firms with longer investment cycles, higher idiosyncratic uncertainty and higher information asymmetry have higher accounting conservatism. This measure captures the information asymmetry by using market-to-book ratio, firm size, leverage, and other variables. Although conservatism has been considered as a constant (Milgrom and Roberts, 1992; Zhang, 2008), many researchers have expressed the need for a firm-level measure of conservatism that can reflect the timing of changes in conservatism and the variation of conservatism across firms within an industry. This firm-year measure successfully meets the researchers' demand. In particular, C-score, a proxy for firm-year measure of conservatism, is estimated from the annual cross-sectional regression model.

\subsection{Voluntary Disclosures}

In many different kinds of voluntary disclosures, I focus on management earnings forecasts as voluntary disclosures because they are known to contain most appropriate information when lenders evaluate a firm's downside risk, comparing to other forms of voluntary disclosures. The primary data source for management earnings disclosures is First Call Historical database (FCHD). Since FCHD started to record firms' voluntary 
disclosures from 2006, my sample period also starts from 2006. I count the frequency of management earnings forecasts in every fiscal year.

\subsection{Debt Financing Data and Sample Selection}

I identify debt financing by using the Standard \& Poor's Compustat North America Industrial Annual File database. Because firms are not expected to pay the reputational cost of increasing disclosures after debt financing for short-term borrowings, I consider only long-term debt financing. Specifically, long-terms debt financing is identified with code, DLTIS. The item includes (1) increase in long-term and short-term debt when combined, (2) long-term debt issued for or assumed in an acquisition, (3) proceeds from bonds, capitalized lease obligations, or note obligations, and (4) reclassification of current debt to long-term debt. I exclude firm-years which are not identified with the code. I also exclude finance and utility firms (i.e., firms with Standard Industrial Classification (SIC) codes of 4000-4999 and 6000-6999) as their capital structure differs from traditional manufacturing firms. Firms which issue or split their stock are also excluded as such events are known to affect a firm's disclosure policy. I also exclude firm-years without control variables which is known to affect a firm's disclosure policy. In addition, I exclude firm-years releasing no disclosures during the entire sample period 1996-2010, assuming that those firms would seldom use disclosures as a vehicle for disclosing their future earnings information. Finally, I exclude firm-years which do not have a C-score. As a result, I test total 2,520 firms and 9,166 firm-years. This procedure is summarized in Table 1.

Table 1. Sample selection process

\begin{tabular}{lcc}
\hline \multicolumn{1}{c}{ Selection criteria } & $\begin{array}{c}\text { Number of firm-years left in } \\
\text { the sample }\end{array}$ & $\begin{array}{c}\text { Number of firms in the } \\
\text { sample }\end{array}$ \\
\hline Firms issuing long-term debt at least once in 1996-2010. & 124,960 & 27,647 \\
Less: firm-years issuing or splitting a stock & 2,371 & 87 \\
Less: financing and utility firms & 15,921 & 3,302 \\
Less: firm-years without control variables & 66,223 & 16,400 \\
\cline { 2 - 3 } & $\mathbf{3 7 , 4 5 1}$ & $\mathbf{8 , 2 1 8}$ \\
Less: firm-years of firms without c-score & 20,460 & 3,701 \\
Less: firm-years of firms reporting zero disclosure & 7,825 & 1,947 \\
\hline TOTAL & $\mathbf{9 , 1 6 6}$ & $\mathbf{2 , 5 7 0}$ \\
\hline
\end{tabular}

\subsection{Research model}

To test my hypothesis, I estimate an ordinary least square (OLS) regression model (1) as described below. Dependent variable, $\triangle M F$, is one-year change in the frequency of management earnings forecasts.

$\Delta M F_{i t}=$

$\beta_{0}+\beta_{1}$ Debt $_{i t}+\beta_{2}$ Conservatism $_{i t}+\beta_{3}$ Debt $_{i t} *$ Conservatism $_{i t}+\beta_{4} \log (M V)_{i t}+\beta_{5}$ Return $_{i t}+\beta_{6}$ StdReturn $_{i t}+$

$\beta_{7}$ Badnews $+\beta_{8} \log (N \text { Analyst })_{i t}+\beta_{9} N S e g_{i t}+\beta_{10} M / B_{i t}+\varepsilon_{i t}$

where Debt is a dummy variable whose value equals to 1 if a firm issues long-term debt during the fiscal year $(t)$ and 0 otherwise. Conservatism indicates a firm's level of conservatism measured by Khan and Watts (2009)'s C-score. My main independent variable of interest is the interaction term between Conservatism and Debt (Debt ${ }^{*}$ Conservatism). As $H 1$ postulates that a firm with a lower conservatism level are more likely to increase management forecast before debt financing, I expect negative coefficient on the interaction term $\left(\beta_{3}<0\right)$.

Following Nagar et al. (2003), I control for various factors which is known to affect the cost or benefit of issuing a forecast. $M V$ is equity market value. I use the natural logarithm of $M V$ since the variable is highly skewed. Return is the annual CRSP stock returns and StdReturn is the annual variability of the stock returns. BadNews is a binary variable whose value equals 1 if a firm experiences a negative annual CRSP stock return in the firm-year and 0 otherwise. The number of analyst followings, NAnalyst, is also controlled since it represents both analysts' information demands and firm-level disclosure tendencies. I convert it to logarithmic number because it is highly 
skewed. Also, I include the number of business segments, NSeg, as reported in the 1997 version of Compustat Segment. NSeg is included to control for a firm's complexity. $M / B$ is a market-to-book ratio which proxies for the information asymmetry between management and investors.

\section{RESULTS}

\subsection{Descriptive Statistics}

Table 2 reports descriptive statistics of variables used in Equation (1). In the table, the mean of $\triangle M F$ are greater at debt financing year than at other times, which implies that firms are more likely to increase their disclosure level around debt financing than at other times. C-Score is lower at debt financing years than at other times. Although prior studies argue that firms with high conservatism level can enjoy lower cost of debt, this result may imply that firms want to deliver more good news quickly than bad news right before debt financing given that their conservatism level are already evaluated in the past. The descriptive statistics of control variables are similar to prior literature arguing that debt financing is a good signal to stock market. That is, $\log (M V)$, Return, $\log ($ NAnalyst), $N S e g$ are greater at debt financing years than at other times while StdReturn, Badnews, and $M / B$ are lower at debt financing years than at other times.

Table 2. Descriptive Statistics

\begin{tabular}{|c|c|c|c|c|c|c|c|c|}
\hline \multirow[b]{2}{*}{ Variables } & \multicolumn{4}{|c|}{ Debt financing years } & \multicolumn{4}{|c|}{ Non-Debt financing years } \\
\hline & $\mathbf{N}$ & Mean & Median & Std. & $\mathbf{N}$ & Mean & Median & Std. \\
\hline \multicolumn{9}{|c|}{ Dependent Variable } \\
\hline$\Delta M F$ & 5,099 & 1.302 & 1.000 & 4.020 & 4,067 & 1.070 & 1.000 & 4.062 \\
\hline \multicolumn{9}{|c|}{ Conservatism Measures } \\
\hline C-Score & 5,099 & 0.067 & 0.072 & 0.088 & 4,067 & 0.087 & 0.096 & 0.074 \\
\hline \multicolumn{9}{|c|}{ Independent Variables } \\
\hline $\log (M V)$ & 5,099 & 3.034 & 0.674 & 3.127 & 4,067 & 2.884 & 2.945 & 0.658 \\
\hline Return & 5,099 & 25.540 & 21.370 & 19.210 & 4,067 & 20.912 & 16.380 & 17.838 \\
\hline StdReturn & 5,099 & 0.200 & 0.170 & 0.145 & 4,067 & 0.255 & 0.215 & 0.196 \\
\hline BadNews & 5,099 & 0.396 & 0.000 & 0.489 & 4,067 & 0.398 & 0.000 & 0.490 \\
\hline $\log ($ NAnalyst $)$ & 5,099 & 2.143 & 2.302 & 0.907 & 4,067 & 2.046 & 2.197 & 0.954 \\
\hline NSeg & 5,099 & 3.333 & 3.000 & 1.821 & 4,067 & 2.784 & 2.000 & 1.432 \\
\hline$M / B$ & 5,099 & 0.097 & 0.102 & 4.774 & 4,067 & 0.311 & 0.139 & 8.682 \\
\hline
\end{tabular}

Table 3 presents Pearson correlation among variables used in the main regression model. Dependent variable $(\triangle M F)$ is positively correlated with Debt and the correlation is statistically significant. It means that firms are more likely to increase the frequency of management earnings forecasts around debt offerings. Consistent with the view of Hui et al. (2008), the correlation between $\triangle M F$ and $C$-score is negative and it is statistically significant. The other correlation between $\triangle M F$ and control variables are generally consistent with Nagar et al. (2003). That is, $\log (M V)$, Return, NAnalyst, and NSeg are positively correlated with $\triangle M F$ while StdReturn, Badnews, M/B are negatively correlated with $\triangle M F$. 
Table 3. Pearson correlation

\begin{tabular}{|c|c|c|c|c|c|c|c|c|c|c|}
\hline Variables & $\Delta M F$ & Debt & C-Score & $\log (M V)$ & Return & StdReturn & Badnews & $\begin{array}{c}\text { Log } \\
\text { (NAnalyst) }\end{array}$ & NSeg & $M / B$ \\
\hline$\Delta M F$ & 1 & & & & & & & & & \\
\hline Debt & $\begin{array}{c}0.029 \\
(0.006) \\
\end{array}$ & 1 & & & & & & & & \\
\hline C-Score & $\begin{array}{c}-0.049 \\
(<.0001)\end{array}$ & $\begin{array}{c}-0.117 \\
(<.0001)\end{array}$ & 1 & & & & & & & \\
\hline $\log (M V)$ & $\begin{array}{c}0.100 \\
(<.0001)\end{array}$ & $\begin{array}{c}0.111 \\
(<.0001)\end{array}$ & $\begin{array}{c}-0.594 \\
(<.0001)\end{array}$ & 1 & & & & & & \\
\hline Return & $\begin{array}{c}0.117 \\
(<.0001) \\
\end{array}$ & $\begin{array}{c}0.123 \\
(<.0001) \\
\end{array}$ & $\begin{array}{c}-0.46 \\
(<.0001) \\
\end{array}$ & $\begin{array}{c}0.725 \\
(<.0001) \\
\end{array}$ & 1 & & & & & \\
\hline StdReturn & $\begin{array}{c}-0.046 \\
(<.0001) \\
\end{array}$ & $\begin{array}{c}-0.161 \\
(<.0001) \\
\end{array}$ & $\begin{array}{c}0.200 \\
(<.0001)\end{array}$ & $\begin{array}{c}-0.335 \\
(<.0001) \\
\end{array}$ & $\begin{array}{c}-0.301 \\
(<.0001) \\
\end{array}$ & 1 & & & & \\
\hline BadNews & $\begin{array}{c}-0.028 \\
(0.008)\end{array}$ & $\begin{array}{l}-0.001 \\
(0.885)\end{array}$ & $\begin{array}{l}-0.025 \\
(0.018)\end{array}$ & $\begin{array}{c}-0.083 \\
(<.0001)\end{array}$ & $\begin{array}{l}-0.030 \\
(0.005)\end{array}$ & $\begin{array}{c}0.035 \\
(0.001)\end{array}$ & 1 & & & \\
\hline Log(Nanalyst) & $\begin{array}{c}0.120 \\
(<.0001) \\
\end{array}$ & $\begin{array}{c}0.052 \\
(<.0001) \\
\end{array}$ & $\begin{array}{c}-0.548 \\
(<.0001) \\
\end{array}$ & $\begin{array}{c}0.605 \\
(<.0001) \\
\end{array}$ & $\begin{array}{c}0.467 \\
(<.0001) \\
\end{array}$ & $\begin{array}{c}-0.146 \\
(<.0001)\end{array}$ & $\begin{array}{c}0.004 \\
(0.699) \\
\end{array}$ & 1 & & \\
\hline NSeg & $\begin{array}{c}0.039 \\
(0.001) \\
\end{array}$ & $\begin{array}{c}0.162 \\
(<.0001) \\
\end{array}$ & $\begin{array}{c}-0.298 \\
(<.0001) \\
\end{array}$ & $\begin{array}{c}0.289 \\
(<.0001) \\
\end{array}$ & $\begin{array}{c}0.258 \\
(<.0001) \\
\end{array}$ & $\begin{array}{c}-0.162 \\
(<.0001) \\
\end{array}$ & $\begin{array}{c}-0.070 \\
(<.0001) \\
\end{array}$ & $\begin{array}{c}0.143 \\
(<.0001) \\
\end{array}$ & 1 & \\
\hline$M / B$ & $\begin{array}{l}-0.006 \\
(0.579) \\
\end{array}$ & $\begin{array}{l}-0.016 \\
(0.135) \\
\end{array}$ & $\begin{array}{c}0.009 \\
(0.388) \\
\end{array}$ & $\begin{array}{c}-0.004 \\
(0.717) \\
\end{array}$ & $\begin{array}{l}-0.009 \\
(0.403)\end{array}$ & $\begin{array}{c}0.013 \\
(0.219) \\
\end{array}$ & $\begin{array}{c}0.008 \\
(0.446) \\
\end{array}$ & $\begin{array}{c}-0.009 \\
(0.399) \\
\end{array}$ & $\begin{array}{c}0.008 \\
(0.462)\end{array}$ & 1 \\
\hline
\end{tabular}

Note: The sample size is 9,166 . The p-values are in parentheses.

\subsection{Multivariate test}

Table 4 represents my OLS regression results. It shows that the estimated coefficients on Debt is significantly positive at one percentage significance level. Consistent with prior studies, it implies that debt financing gives firms incentives to increase their disclosure level before debt financing. Contrast to my expectation, the coefficient on Conservatism is significantly positive. However, the positive effect of conservatism on a firm's disclosure policy is mitigated around debt financing. In other words, as seen the negative coefficient on the interaction term between Debt and Conservatism, the relation between voluntary disclosures and conservatism change from complementary to substitute relationship around debt financing.

The results for the control variables are generally consistent with my expectations. Particular, $\triangle M F$ is positively related to Return and $\log$ (NAnalyst) while it is negatively related to StdReturn and NSeg. However, consistent with my expectation, the coefficient on $M V$ is significantly negative.

Table 4. Multivariate Analysis

\begin{tabular}{|c|c|c|c|}
\hline Variables & Expected Sign & Coefficient & (t-value) \\
\hline Intercept & & -0.49 & $(-1.46)$ \\
\hline Debt & $(+)$ & $0.37 * * *$ & $(3.07)$ \\
\hline Conservatism & $(-)$ & $4.65 * * *$ & $(4.81)$ \\
\hline Debt*Conservatism & $(-)$ & $-3.10 * * *$ & $(-2.96)$ \\
\hline \multicolumn{4}{|l|}{ Controls } \\
\hline $\log (M V)$ & $(+)$ & -0.06 & $(-0.53)$ \\
\hline Return & $(+)$ & $0.02 * * *$ & $(5.80)$ \\
\hline StdReturn & $(-)$ & -0.27 & $(-1.04)$ \\
\hline Badnews & $(-)$ & $-0.19 * *$ & $(-2.20)$ \\
\hline $\log$ (Nanalyst) & $(+)$ & $0.49 * * *$ & $(8.19)$ \\
\hline NSeg & $(-)$ & 0.03 & $(1.01)$ \\
\hline$M / B$ & $(-)$ & -0.01 & $(-0.41)$ \\
\hline $\mathrm{N}$ & & 9,166 & \\
\hline Pseudo $\mathrm{R}^{2}$ & & 0.022 & \\
\hline
\end{tabular}




\subsection{Matching}

To control for systematic difference between debt financing years and non-debt financing years, I matched debt financing years with non-debt financing years to have similar size, same industry, and same fiscal year-end. Through this matching process, I obtain 600 pairs.

Table 5 presents the regression results with matched sample. It shows that the negative coefficient on the interaction term between Debt and Conservatism remains significantly. The signs of other variables are also similar to those in Table 4 but their statistic significances are not strong.

Table 5. Matched Sample

\begin{tabular}{lccc}
\hline \multicolumn{1}{c}{ Variables } & Expected Sign & Coefficients & (t-value) \\
\hline Intercept & & 0.07 & $(0.06)$ \\
Debt & $(+)$ & 0.24 & $(0.69)$ \\
Conservatism & - (- & 5.65 & $(1.34)$ \\
Debt ${ }^{*}$ Conservatism & $(-)$ & $-4.32^{* *}$ & $(-2.04)$ \\
\hline Controls & & & $(0.10)$ \\
\hline $\log ($ MV $)$ & $(+)$ & 0.04 & $(2.21)$ \\
Return & $(+)$ & $0.02^{* *}$ & $(-0.43)$ \\
StdReturn & $(-)$ & -0.52 & $(-1.06)$ \\
BadNews & $(-)$ & -0.28 & $(0.74)$ \\
log(NAnalyst $)$ & $(+)$ & 0.13 & $(-0.31)$ \\
NSeg & $(-)$ & -0.03 & $(-0.26)$ \\
M/B & $(-)$ & -0.16 & \\
$\mathrm{~N}$ & & 1,200 & \\
Pseudo R & -0.0014 & \\
\hline
\end{tabular}

\subsection{Good News vs Bad News}

Additionally, I examine the nature of disclosures around debt financing and its relation with accounting conservatism. As I hypothesize in $\mathrm{H} 2$, although firms tend to disclose more positive news (or less bad news) before debt financing, accounting conservatism is defined as a policy that forces a firm to recognize bad news quickly and good news slowly. Therefore, if the relation between conservatism on voluntary disclosures is substitute, more conservative firms are less (more) likely to increase bad news (good news) around debt financing.

To classify each management earnings forecast as either good news or bad news, I use code in FCHD, CIGCODED. The item indicates whether the voluntary disclosure qualifies as a positive or negative surprise. If a management earnings forecasts is higher than analysts' consensus, it is classified as a positive surprise and otherwise, it is classified as a negative surprise. Next, I annually calculate the ratio of good news to total management earnings forecasts. Dependent variable in this test is one-year change in the ratio of good news. Independent variables are the same with those in previous tests. If $\mathrm{H} 2$ is true, the coefficient on the interaction term between Debt and Conservatism would be insignificant.

Table 6 presents the regression results with one-year change in the ratio of good news as a dependent variable. It shows that the coefficient on Conservatism is significantly negative but the coefficient on the interaction term between Debt and Conservatism is not statistically significant. This result implies that although firms with higher conservatism level tend to release more bad news, the tendency disappears around debt financing. 
Table 6. Good news vs Bad news

\begin{tabular}{lccc}
\hline \multicolumn{1}{c}{ Variables } & Predicted Sign & Coefficients & (t-value) \\
\hline Intercept & & 0.03 & $(2.10)$ \\
Debt & $(+)$ & 0.01 & $(0.47)$ \\
Conservatism & $(-)$ & $-0.07 *$ & $(-1.72)$ \\
Debt ${ }^{\text {Conservatism }}$ & $(-)$ & -0.04 & $(-0.79)$ \\
Controls & & & $(-0.18)$ \\
log $(M V)$ & $(+)$ & -0.01 & $(1.15)$ \\
Return & $(+)$ & 0.01 & $(-1.99)$ \\
StdReturn & $(-)$ & $0.03 * *$ & $(7.46)$ \\
BadNews & $(+)$ & $0.03 * * *$ & $(1.34)$ \\
log(NAnalyst) & $(+)$ & 0.01 & $(-2.63)$ \\
NSeg & $(-)$ & $-0.01 * * *$ & $(-1.41)$ \\
M/B & $(-)$ & -0.01 & \\
N & & 7,345 & 0.014 \\
Pseudo R ${ }^{2}$ & & &
\end{tabular}

\section{SUMMARY AND CONCLUSION}

This paper examines the dynamic relationship between voluntary disclosures and accounting conservatism. I find that firms with less conservatism level are more likely to increase their voluntary disclosures around debt financing. It implies that the relations between voluntary disclosures and accounting conservatism is not static but dynamic. Specifically, the relation between voluntary disclosures and accounting conservatism seems to be complementary but it becomes substitute around debt financing. In addition, I examine the nature of the voluntary disclosures around debt financing and I find that firms with higher conservatism levels do not necessarily increase good news, possibly due to the limitation on their conservatism level.

Despite the several contribution of this paper, it also has some limitations. Due to the limitation on data access, I could not identify the exact date of debt financing. I expect that the substitute relation between voluntary disclosures and accounting conservatism becomes much stronger right before debt financing. Also, could not identify the amount of debt financing. If there is substitute relation between voluntary disclosures and conservatism in reducing information asymmetry around debt financing, the relation would be stronger as the amount of debt financing increases.

\section{AUTHOR INFORMATION}

Kyoungwon Mo is Ph.D in accounting at KAIST and currently served as a visiting professor in accounting at SungKunKwan University in South Korea. Email: modeng1@business.kaist.ac.kr

\section{REFERENCES}

Ahmed, A.S. \& Billings, B.K. \& Morton, R.M. \& Stanford-Harris, M. (2002). The role of accounting conservatism in mitigating bondholder-shareholder conflicts over dividend policy and in reducing debt costs. The Accounting Review 77(4) 867-890.

Cahan, S.F. \& Zhang, W. (2006). After Enron: auditor conservatism and Ex-Anderson clients. The Accounting Review 81(2006) 49-82.

Fischer, P.E. \& Verrecchia R.E. (2010). The Effect of Limited Liability on the Market Response to Disclosure. Contemporary Accounting Research 16(3) 515-541.

Frankel, R. \& McNichols, M. \& Wilson, G. P. (1995). Discretionary disclosure and external financing. The Accounting Review 70(1) 135-150.

Givoly, D. \& Hayn, C. (2000). The changing time-series properties of earnings, cash flows and accruals: has financial accounting become more conservative?. Journal of Accounting and Economics 29(2000) 287-320

Healy, P. M. \& Hutton, A. P. \& Palepu, K. G. (1999). Stock performance and intermediation changes surrounding sustained increases in disclosure. Contemporary Accounting Research 16(3) 485-520.

Hui, K.W. \& Matsunaga, S. \& Morse, D. (2009). The impact of conservatism on management earnings forecasts. 
Journal of Accounting and Economics, 47(3) 192-207.

Kasznik, R. \& Lev, B. (1995). To warn or not to warn: management disclosures in the face of an earnings surprise. The Accounting Review 70(1995) 113-134.

Khan, M. \& Watts, R.L. (2009). Estimation and empirical properties of a firm-year measure of accounting conservatism. Journal of Accounting and Economics, 48(2-3) 132-150.

LaFond, R. \& Watts, R.L. (2008). The information role of conservatism. The Accounting Review, 83(2008) 447-478.

Li, \& Jing. (2008). Accounting conservatism, information uncertainty and analysts' forecasts. Working Paper, Columbia University.

Li, \& Zining. (2008). Accounting conservatism and managers' forecasting behavior. Working Paper, Southern Methodist University.

Louis, H. \& Lys, T. \& Sun, A.X. (2008). Conservatism and analyst earnings forecast bias. Working Paper, Pennsylvania State University.

Mazumdar, S. C., \& Sengupta, P. (2005). Corporate disclosure and the loan spread on private debt. Financial Analysts Journal, 61(3) 83-95.

Milgrom, P. \& Roberts, J. (1992) Economics, organization \& management, PrenticeHall, Inc., Englewood Cliffs, NJ.

Moerman, R. (2008). The role of information asymmetry and financial reporting quality in debt trading: Evidence from the secondary loan market. Journal of Accounting and Economics 46(2-3) 240-260.

Nagar, V. \& Nanda, D. \& Wysockic, P. (2003). Discretionary disclosure and stock-based incentives. Journal of Accounting and Economics 34(1-3) 283-309.

Plummer, C.E. \& Tse, S.Y. (1999). The Effect of Limited Liability on the Informativeness of Earnings: Evidence from the Stock and Bond Markets. Contemporary Accounting Research 16(3) 541-574.

Sengupta, P. (1998). Corporate disclosure quality and the cost of debt. The Accounting Review 73(4) 459-474.

Skinner, D. J. (1994). Why firms voluntarily disclose bad news. Journal of Accounting Research 32(1) 38-60.

Watts, R. (2003a). Conservatism in accounting. Part I: Explanations and implications. Accounting Horizons 17(3) 207-221.

Watts, R. (2003b). Conservatism in accounting. Part II: Evidence and research opportunities. Accounting Horizons 17(4) 287-301.

Watts, R., \& Zimmerman J.L. (1986). Positive Accounting Theory. Prentice-Hall.

Zhang, J. (2008). The contracting benefits of accounting conservatism to lenders and borrowers. Journal of Accounting and Economics 45(2008), 27-54. 